\title{
Pulmonary Vascular Effects of Exogenous Atrial Natriuretic Peptide in Sheep Fetuses
}

\author{
BARBARA HARGRAVE, ${ }^{\mathrm{I}}$ CHRISTINE ROMAN, PATRICE MORVILLE, ${ }^{2}$ AND MICHAEL HEYMANN \\ Departments of Pediatrics, Physiology, and Obstetrics, Gynecology and Reproductive Sciences, and \\ Cardiovascular Research Institute, University of California, San Francisco, California 94143
}

\begin{abstract}
In the adult, atrial natriuretic peptide (ANP) regulates renal and cardiovascular function when blood volume is expanded, when atrial pressure is increased, and when arterial oxygen content is decreased. In late gestation fetal sheep, plasma ANP concentrations are higher than in pregnant adults; however, ANP function in the fetus is unclear. To assess the possible role of ANP in mediating changes in pulmonary blood flow, we studied six chronically cannulated fetal sheep at 132-134 d gestation (term $145 \mathrm{~d})$. We infused ANP in doses of 4.0 \pm 0.48, 16.0 \pm 1.9 , and $64.0 \pm 7.7 \mathrm{ng} / \mathrm{kg} / \mathrm{min}$, and vehicle into all fetuses. ANP increased hematocrit, which suggests that blood volume decreased. Pulmonary blood flow, measured by the radionuclide-labeled microsphere technique, increased in response to the 4.0, 16.0, and $64.0 \mathrm{ng} / \mathrm{kg} / \mathrm{min}$ dose ANP infusions from a control value of $126.5 \pm 32.2$ to $141.8 \pm$ 26.9 to $170.4 \pm 37.2$ to $300.8 \pm 84.8^{*} \mathrm{~mL} / \mathrm{min} / 100 \mathrm{~g}\left({ }^{*} p\right.$ $<0.05$ ), respectively, and calculated pulmonary vascular resistance decreased from a control value of $0.45 \pm 0.08$ to $0.42 \pm 0.08$ to $0.43 \pm 0.09$ to $0.21 \pm 0.04^{*}\left({ }^{*} p<0.05\right)$ $\mathrm{mm} \mathrm{Hg} / \mathrm{mL} / \mathrm{min} / \mathrm{kg}$, respectively. Pulmonary blood flow decreased to $54.5 \pm 6.0 \mathrm{~mL} / \mathrm{min} / 100 \mathrm{~g}$ and calculated pulmonary vascular resistance increased to $0.81 \pm 0.09$ $\mathrm{mm} \mathrm{Hg} / \mathrm{mL} / \mathrm{min} / \mathrm{kg}$ during the recovery period. Mean pulmonary and carotid arterial blood pressures, venous blood pressure, and heart rate did not change significantly. Thus, ANP may play a role in maintaining right ventricular output in the fetus by increasing pulmonary blood flow through its ability to decrease pulmonary vascular resistance. (Pediatr Res 27: 140-143, 1990)
\end{abstract}

\section{Abbreviations}

ANP, atrial natriuretic peptide

i.d., inner diameter

o.d., outer diameter

ANP is a peptide hormone found in the cardiac atria and lungs of many adult mammalian species (1-3). Plasma ANP concentrations increase when extracellular fluid volume is expanded, when atrial pressure is increased (1), and when arterial oxygen content is decreased (4). Increased plasma ANP concentrations have a variety of renal, cardiovascular, endocrine, and pulmo-

Received June 29, 1989; accepted September 25, 1989.

Correspondence Michael A. Heymann, M.D., Box 0544, HSE 1403, University of California, San Francisco, San Francisco, CA 94143.

Supported by N1H Grant 40473.

${ }^{1}$ Present address Department of Biological Sciences, Old Dominion University, Norfolk, VA 23529.

${ }^{2}$ Present address American Memorial Hospital, 49 Rue Cognac Jay, 51100 Reims, France. nary effects $(4,5)$. Large doses of ANP cause diuresis and natriuresis (5), a decrease in arterial blood pressure and cardiac output (6), inhibition of renin secretion after a decrease in renal perfusion pressure (7), inhibition of aldosterone and vasopressin secretion in vitro (5), and pulmonary vasodilation after chronic hypoxemia (4).

ANP is present in fetal cardiac atria, ventricles (8), and lungs (9); because gas exchange does not occur in the fetal lung, the latter finding suggests that ANP may play a role in regulating the pulmonary vasculature in the fetus. Basal arterial plasma ANP concentrations are greater in the fetus than in the pregnant adult and increase further after volume expansion and acute hypoxemia $(10,11)$. Increases in plasma ANP concentrations within a physiologic range decrease combined ventricular output and umbilical-placental blood flow (12), but do not significantly alter mean arterial blood pressure or heart rate $(12,13)$. At present, relatively little is known about the effects of ANP on the fetal pulmonary vasculature. Because changes in circulatory dynamics stimulate ANP secretion in the fetus, we considered that the release of ANP into the circulation might play a role in regulating blood flow distribution by changing pulmonary blood flow. To more closely examine the relationships between plasma ANP concentrations and pulmonary blood flow in the fetus, we infused ANP into fetal sheep and measured pulmonary blood flow.

\section{MATERIALS AND METHODS}

Surgical procedures. Pregnant ewes were fasted for 24-36 h before surgery (protocol approved by the Committee on Animal Research, UCSF). Epidural anesthesia was induced by injecting $4 \mathrm{~mL}$ tetracaine $\mathrm{HCl}$ (Pontocaine $\mathrm{HCl}$, Breon Laboratories, New York, NY). A local anesthetic $(0.25 \%$ lidocaine hydrochloride) was injected subcutaneously before each maternal and fetal skin incision. Polyvinyl catheters (1.3 $\mathrm{mm}$ i.d., $2.3 \mathrm{~mm}$ o.d.) were placed in the left pedal artery and vein of the ewe and advanced to the descending aorta and inferior vena cava, respectively. Ten percent dextrose in $0.9 \% \mathrm{NaCl}$ solution was infused continuously into the ewe, and ketamine was given intravenously in 5-100 mg amounts every 15-20 min.

The uterus was exposed through a midline incision in the ewe's abdomen. An incision $(2.5 \mathrm{~cm})$ was made in the uterus to expose the fetal hindlimbs. Polyvinyl catheters $(0.8 \mathrm{~mm}$ i.d., $1.2 \mathrm{~mm}$ o.d.) were placed in a pedal vein and artery and advanced, respectively, to the inferior vena cava for injection of radionuclide-labeled microspheres and to the descending aorta for measurement of arterial blood pressure and withdrawal of blood samples. A catheter $(1.3 \mathrm{~mm}$ i.d., $2.3 \mathrm{~mm}$ o.d.) was also placed in the amniotic fluid cavity for measurement of amniotic fluid pressure.

A second uterine incision was made and the pulmonary trunk and left pulmonary artery were exposed through a left thoracotomy. A catheter [ $1 \mathrm{~cm}$ of the tapered tip of a 20 -gauge Teflon IV cannula $(0.63 \mathrm{~mm}$ i.d., $1.07 \mathrm{~mm}$ o.d.) connected to flexible 
polyvinyl tubing] was placed in the pulmonary artery for the measurement of pulmonary arterial pressure and for withdrawal of both a microsphere reference sample and blood samples for chemical analysis. Details of this procedure have been described elsewhere (14). Briefly, a suture was placed in the adventitial layer of the pulmonary trunk midway between the pulmonary valve and the origin of the ductus arteriosus, and the catheter inserted and secured in place by tying the suture around the polyvinyl ring. The same type of catheter described above was placed in the left atrium for the measurement of left atrial pressure and for withdrawal of blood samples. In addition, an electromagnetic flow transducer was placed around the left pulmonary artery. The thoracotomy was closed.

The fetal neck was exposed through the same uterine incision. Polyvinyl catheters $(0.8 \mathrm{~mm}$ i.d., $1.2 \mathrm{~mm}$ o.d.) were inserted into the carotid artery and jugular vein and advanced to the ascending aorta for withdrawal of blood samples and to the superior vena cava for the infusion of ANP.

All incisions were sutured, and all catheters and the electromagnetic flow transducer cord were exteriorized at the maternal flank and placed in a cloth pouch for protection. At the end of surgery and daily thereafter, antibiotics were placed in the amniotic sac and given intravenously to the ewe (100 mg gentamicin and 1 million $U$ penicillin G). Antibiotics were not given on the day of the experiment. All animals were allowed at least $2 \mathrm{~d}$ to recover from surgery before any experiments were performed. All ewes were housed in individual cages and allowed free access to food and water.

Experimental protocol. We studied six chronically cannulated fetuses at gestational ages of 132-134 d (term 145 d). We infused ANP and vehicle ( $5 \%$ dextrose in $0.9 \% \mathrm{NaCl}$ ) into the superior vena cava of all fetuses.

On the day of the experiment, the ewe was placed in a mobile cart, brought to the laboratory, and allowed at least $1 \mathrm{~h}$ to acclimate to its surroundings. The catheters were opened and filled with fresh heparin-saline solution, and the electromagnetic flow transducer connected to the flow meter. Fetal arterial pressure, amniotic pressure, left pulmonary artery blood flow, and heart rate were monitored throughout the experiments (the pressures with Statham $\mathrm{P} 23 \mathrm{Db}$ strain gauge transducers and flow with a Statham SP2202 meter, Statham Instruments, Oxnard, $\mathrm{CA}$ ) and recorded continuously on a Beckman recorder (Beckman Instruments, Inc., Palo Alto, CA). Fetal heart rate was measured by a cardiotachometer triggered by an arterial pulse wave. All fetal arterial pressures were corrected to amniotic fluid pressure as zero reference.

The 150-min experiment was divided into a 30-min control period, three 30-min ANP infusion periods, and a 30-min recovery period. ANP (hANP 1-28, Peninsula Laboratories, Belmont, $\mathrm{CA} ; 0.1 \mathrm{~mL} / \mathrm{min}$ ) was infused at 16,64 , and $256 \mathrm{ng} / \mathrm{min}$ (selected randomly). Fetal wt ranged from 3.3 to $4.6 \mathrm{~kg}(4.1 \pm 0.21 \mathrm{~kg}$, mean $\pm \mathrm{SE}$ ). Corrected for body wt, the infused doses of ANP were $4.0 \pm 0.48,16.0 \pm 1.9$, and $64.0 \pm 7.7 \mathrm{ng} / \mathrm{kg} / \mathrm{min}$. Each animal also received a 30 -min infusion of $5 \%$ dextrose in $0.9 \%$ $\mathrm{NaC} 1$ at $0.1 \mathrm{~mL} / \mathrm{min}$ and served as its own control.

During control, infusion, and recovery periods, pulmonary and carotid arterial and left atrial blood samples were collected $(3 \mathrm{~mL})$. Blood samples were collected in heparinized syringes, placed in tubes containing EDTA $(6 \mathrm{mg}$ ) and aprotinin (Trasylol $150 \mathrm{KIU} / \mathrm{mL}$ ), and immediately placed on ice. The plasma was separated and stored frozen at $-70^{\circ} \mathrm{C}$ until extraction.

At the end of the control period, each infusion period, and the recovery period, radionuclide-labeled microspheres were injected for determination of pulmonary flow as described previously (15). Briefly, microspheres labeled with one of ${ }^{153} \mathrm{Gd},{ }^{57} \mathrm{Co},{ }^{114} \mathrm{In}$, ${ }^{51} \mathrm{Cr},{ }^{113} \mathrm{Sn},{ }^{85} \mathrm{Sr},{ }^{95} \mathrm{Nb},{ }^{54} \mathrm{Mn}$, or ${ }^{65} \mathrm{Zn}$ were injected into the inferior vena cava of the fetus while blood was withdrawn from the pulmonary arterial catheter at a rate of $3.88 \mathrm{~mL} / \mathrm{min}$ (reference sample). The reference sample was collected starting $10 \mathrm{~s}$ before the microsphere injection was begun and ending $45 \mathrm{~s}$ after the injection was completed. Blood removed for the reference sample and for chemical analysis was replaced with an equal volume of fetal or maternal blood at the time of sampling. At the end of the study, the ewe and fetus were killed with an intravenous injection of sodium pentobarbital, and the fetal lungs were dissected. To calculate lung blood flow, the lungs were incinerated and radioactivity counted in a multichannel pulse analyzer. Blood flow to the lungs was calculated as flow lungs $=$ $\mathrm{cpm}$ in lungs/cpm in pulmonary artery $(\mathrm{Pa})$ reference sample $\mathrm{x}$ flow $_{\mathrm{Pa}}$ reference sample. These flow measurements and measured mean pulmonary arterial and left atrial pressures were used to calculate pulmonary vascular resistance.

Assays. Plasma atrial natriuretic peptide concentrations were measured by RIA using a kit (Alpha ANP $\left[{ }^{125} \mathrm{I}\right]$ RIA System, Amersham, Arlington Heights, IL). All plasma samples were extracted on $\mathrm{C}_{18}$ columns (Sep Pak, Waters Associates, Milford, MA). Each column was washed with methanol and distilled water. Plasma samples $(1 \mathrm{~mL})$ were added to the column and eluted with methanol/trifluroacetic acid. The eluates were dried under nitrogen and reconstituted with assay buffer $(500 \mu \mathrm{L})$. Duplicate $100 \mu \mathrm{L}$ plasma extract or standard was then assayed. Because all plasma samples were extracted, an extracted standard curve was also prepared using charcoal-treated plasma. The two standard curves were parallel, and intraassay and interassay coefficients of variation were 13 and $22 \%$, respectively $(n=6)$.

Fetal and maternal arterial blood $\mathrm{pH}, \mathrm{PCO}_{2}$, and $\mathrm{PO}_{2}$ were determined on a Corning 158 Blood Gas Analyzer (Corning Medical, Medfield, MA). Blood $\mathrm{Hb}$ concentration and arterial blood oxygen saturation were measured on a Radiometer hemoximeter $\left(\mathrm{OSM}_{2}\right.$, Copenhagen, Denmark). Hematocrit was measured using the microcapillary technique, and plasma protein concentrations were determined by refractometry.

Data analysis. Responses of the measured variables to ANP administration were analyzed by one-way analysis of variance corrected for repeated measures. A Fisher's test was used to determine which means were statistically different from control values. Fetal blood pressure and heart rate values were obtained by averaging five points every $5 \mathrm{~min}$ during the last $15 \mathrm{~min}$ of the control and the last $15 \mathrm{~min}$ of each infusion period. Means were considered to be significantly different if $p<0.05$. All data are reported as mean $\pm \mathrm{SE}$.

\section{RESULTS}

Fetal blood gases and $\mathrm{pH}$ were within normal limits and did not change during ANP infusion (Table 1). In response to the 4, 16 , and $64 \mathrm{ng} / \mathrm{kg} / \mathrm{min}$ infusions of ANP, fetal plasma ANP concentrations in pulmonary arterial blood increased from control values of $188.9 \pm 15.6 \mathrm{pg} / \mathrm{mL}$ to $261.7 \pm 12.3$ to $591.3 \pm$ $100.9(p<0.05)$, and to $982.1 \pm 186.3 \mathrm{pg} / \mathrm{mL}(p<0.05)$, respectively, and returned to slightly below control during the recovery period (140.5 $\pm 17.4 \mathrm{pg} / \mathrm{mL})$. Plasma ANP concentrations $(192.2 \pm 16.4 \mathrm{pg} / \mathrm{mL})$ did not change significantly from control when vehicle was infused.

Fetal plasma ANP concentrations in carotid arterial blood increased from control values of $89.7 \pm 16.2 \mathrm{pg} / \mathrm{mL}$ to $159.7 \pm$ 5.4 , to $289.1 \pm 23.7(p<0.05)$, and to $838.0 \pm 132.9 \mathrm{pg} / \mathrm{mL}(p$ $<0.05$ ), respectively, and returned to slightly above control $(101.5 \pm 22.3 \mathrm{pg} / \mathrm{mL})$ once the ANP infusion was stopped. Plasma ANP concentrations did not change significantly from control $(100.6 \pm 34.1)$ when vehicle was infused.

Fetal plasma ANP concentrations in left atrial blood increased from control values of $46.2 \pm 16.1$ to $94.6 \pm 31.2$ to $254.8 \pm$ 39.9 to $699.5 \pm 289.4 \mathrm{pg} / \mathrm{mL}(p<0.05)$, respectively, and returned to slightly above control during the recovery period $(63.0 \pm 23.6 \mathrm{pg} / \mathrm{mL})$. Plasma ANP concentrations did not change significantly from control during the vehicle infusion $(83.5 \pm$ 9.8). Maternal plasma ANP concentrations did not change significantly from control values of $65.0 \pm 14.0 \mathrm{pg} / \mathrm{mL}$ during fetal ANP infusion and were lower than basal ANP concentrations in 
Table 1. Effects of atrial natriuretic peptide infusion on blood composition in six fetal lambs (mean $\pm S E$ )

\begin{tabular}{lccccccc}
\hline & $\mathrm{pH}$ & $\begin{array}{c}\mathrm{PCO}_{2} \\
(\mathrm{~mm} \mathrm{Hg})\end{array}$ & $\begin{array}{c}\mathrm{PO}_{2} \\
(\mathrm{~mm} \mathrm{Hg})\end{array}$ & $\begin{array}{c}\mathrm{O}_{2} \text { saturation } \\
(\%)\end{array}$ & $\begin{array}{c}\text { Hematocrit } \\
(\mathrm{g} / \mathrm{dL})\end{array}$ & $\begin{array}{c}\text { Protein } \\
(\mathrm{g} / \mathrm{dL})\end{array}$ & $\begin{array}{c}\mathrm{Hb} \\
(\mathrm{g} / \mathrm{dL})\end{array}$ \\
\hline $\begin{array}{l}\text { Control } \\
\text { ANP infusions (ng) }\end{array}$ & $7.37 \pm 0.02$ & $51.0 \pm 1.9$ & $24.1 \pm 0.63$ & $57.3 \pm 2.6$ & $32.7 \pm 2.4$ & $3.6 \pm 0.11$ & $10.5 \pm 0.76$ \\
$\quad \mathrm{~kg} / \mathrm{min})$ & & & & & & & \\
$\quad 4$ & $7.39 \pm 0.02$ & $51.3 \pm 1.6$ & $23.3 \pm 0.87$ & $55.5 \pm 3.1$ & $32.6 \pm 2.5$ & $3.8 \pm 0.14$ & $10.4 \pm 0.71$ \\
16 & $7.38 \pm 0.01$ & $51.4 \pm 1.7$ & $23.8 \pm 0.69$ & $56.7 \pm 2.8$ & $32.0 \pm 2.8$ & $3.9 \pm 0.15$ & $10.1 \pm 0.97$ \\
64 & $7.37 \pm 0.02$ & $51.6 \pm 2.4$ & $22.4 \pm 1.5$ & $53.8 \pm 2.7$ & $34.5 \pm 2.5^{*}$ & $3.9 \pm 0.15$ & $10.8 \pm 0.85$ \\
\hline
\end{tabular}

$* p<0.05$ versus control.

the fetus. As shown in Figure 1, pulmonary arterial plasma ANP concentrations were higher than in carotid arterial or left atrial blood.

With the 4- and $16-\mathrm{ng} / \mathrm{kg} / \mathrm{min}$ infusions, ANP produced minimal effects on the hemodynamic variables we measured. When plasma ANP concentrations were increased further with the 64$\mathrm{ng} / \mathrm{kg} / \mathrm{min}$ infusion, we observed a $58 \%$ increase in pulmonary blood flow (Fig. 2, upper panel) and a 44\% decrease in calculated pulmonary vascular resistance (Fig. 2, lower panel). However, mean arterial and venous pressures, left atrial pressure, and heart rate (Table 2) did not change significantly. Left pulmonary arterial blood flow, continuously monitored with the electromagnetic flow transducer, increased within 2-3 min and thereafter remained constant at each level throughout the $30 \mathrm{~min}$ of infusion.

Table 1 shows results for hematocrit, plasma protein concentrations, and $\mathrm{Hb}$. At the highest infusion rate only, hematocrit increased from $32.7 \pm 2.4$ to $34.5 \pm 2.5 \%(p<0.05)$. Although there was a tendency for $\mathrm{Hb}$ and plasma protein concentrations to increase, these changes were not statistically significant. Collectively, these data suggest that ANP decreased blood volume by approximately $3 \%$. During the vehicle infusion no significant changes were observed in plasma ANP concentration, pulmonary blood flow, hematocrit, $\mathrm{Hb}$, or protein concentrations.

\section{DISCUSSION}

The doses of ANP used in this study were chosen to increase fetal plasma ANP concentrations within a physiologic range. Previous studies have shown that volume expansion of fetuses with isotonic saline increases plasma ANP concentrations from $115 \pm 24$ to $409 \pm 72 \mathrm{pg} / \mathrm{mL}$ (11). Similarly, when fetuses were made severely hypoxemic, plasma ANP concentrations increased from $127 \pm 13$ to $565 \mathrm{pg} / \mathrm{mL}$ at the end of hypoxia and to 1490 $\mathrm{pg} / \mathrm{mL}$ during the recovery period (10). Thus, ANP doses used in these studies increased fetal plasma ANP concentrations to levels similar to those observed when the fetus was mildly volume expanded, and to ranges observed during marked decreases in arterial oxygen content. Our results demonstrate that the plasma ANP concentrations achieved with the 4 and $16 \mathrm{ng} / \mathrm{kg} / \mathrm{min}$ infusions were associated with minimal and statistically insignificant changes in pulmonary or cardiovascular function. However, the larger plasma ANP concentration achieved with the 64 $\mathrm{ng} / \mathrm{kg} / \mathrm{min}$ infusion was associated with significant changes in pulmonary blood flow and pulmonary vascular resistance. This implies that acutely, high plasma ANP concentrations are required to effect pulmonary vascular changes in the fetus.

The $64-\mathrm{ng} / \mathrm{kg} / \mathrm{min}$ ANP infusion increased pulmonary blood flow by $58 \%$ and decreased pulmonary vascular resistance by $44 \%$, but did not significantly change mean pulmonary or carotid arterial blood pressures, venous blood pressure, or heart rate. The decrease in pulmonary vascular resistance is in agreement with findings in chronically hypoxemic adults, in which ANP has been shown to decrease pulmonary vascular resistance (4). The mechanism responsible for the increase in pulmonary blood flow and the decrease in pulmonary vascular resistance is not fully understood. A possible explanation for the observed in-

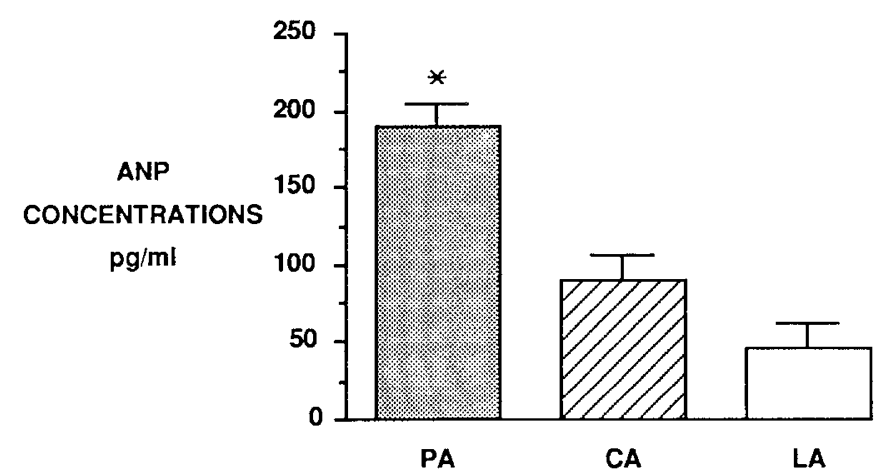

Fig. 1. Normal (control) pulmonary and carotid arterial and plasma ANP concentrations in six fetal lambs. Data are expressed as mean \pm $\mathrm{SE},{ }^{*} p<0.05$.

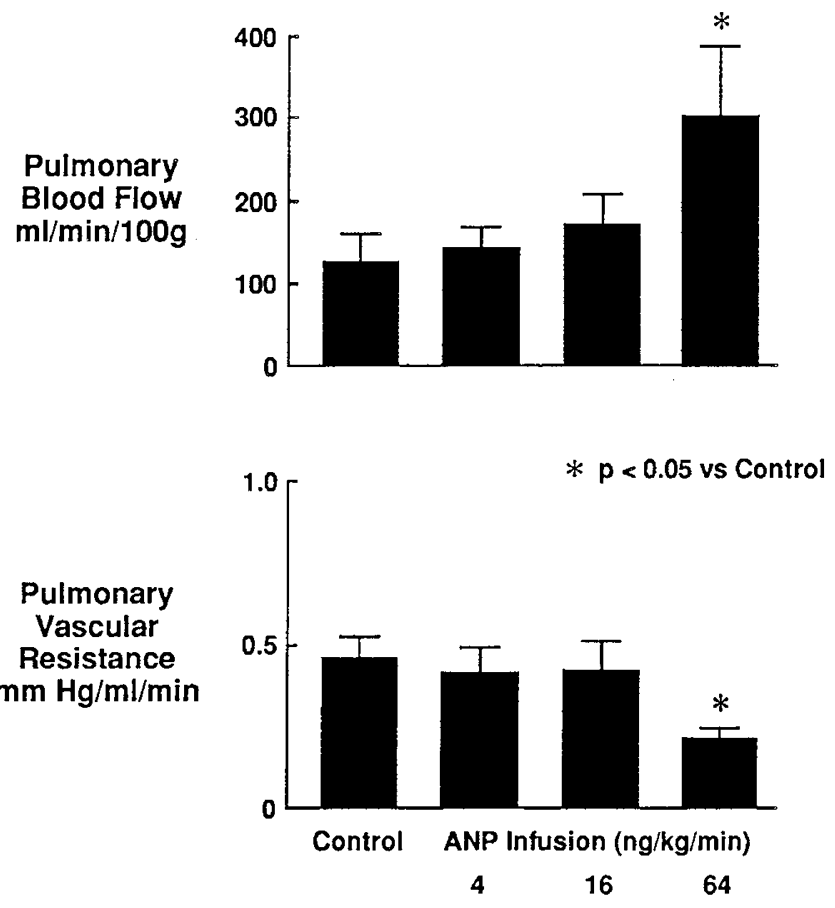

Fig. 2. Effects of ANP infusions on pulmonary blood flow and calculated pulmonary vascular resistance in six fetal lambs. Data are expressed as mean $\pm \mathrm{SE},{ }^{*} p<0.05$.

crease in pulmonary blood flow is the direct effect of ANP on the pulmonary vasculature to decrease pulmonary vascular resistance and to increase pulmonary blood flow. Bianchi et al. (3) have shown that ANP receptors are present in the lung, and the effect seen may have been produced by interaction with these types of receptors, thereby activating guanylate cyclase to produce cyclic GMP, which mediates smooth muscle relaxation (16). Because the pulmonary vasculature of the fetus is con- 
EFFECTS OF ANP FETAL SHEEP

Table 2. Effects of atrial natriuretic peptide infusion on cardiovascular function in six fetal lambs (mean $\pm S E$ )

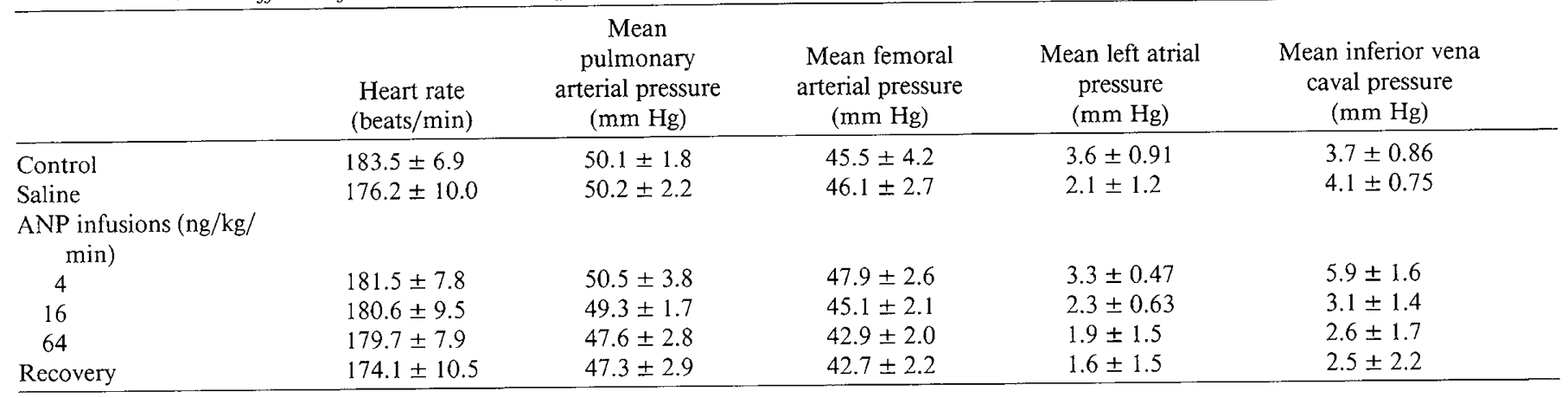

stricted during gestation, our observed change in pulmonary vascular resistance is consistent with in vitro studies in adults by Chou et al. (17) and Morice et al. (18) who demonstrated that ANP is a direct relaxant of pulmonary artery segments and has potent relaxant effects on isolated segments of pulmonary artery. In addition, in vivo studies by Tadepalli and Krueger (19) have shown that ANP infusion blunts acute hypoxemia-induced pulmonary vasoconstriction.

Under basal conditions, plasma ANP concentrations were greater in the pulmonary artery than in the carotid artery or left atrium. These data demonstrate that in the sheep fetus the majority of ANP found in the plasma is produced by the right side of the heart and may reflect the higher right ventricular afterload found normally in the fetus. The fact that the plasma ANP concentration was greater in the pulmonary artery than in both the left atrium and carotid artery, suggests that ANP may be removed from the fetal circulation by the lungs. This is in agreement with reports by Turrin and Gillis (20) showing that ANP is cleared by the lungs in adult rabbits.

At birth many changes take place in the fetal circulation. During lung expansion and the initiation of ventilation, pulmonary arterial pressure and pulmonary vascular resistance decrease $(21,22)$. ANP may play a role in this process; further studies are needed to test this hypothesis. The primary hypothesis behind these studies was that increases in right ventricular afterload, and thereby potential alterations in stroke volume or output (23), that might occur during stress could be modulated by right-sided ANP release, pulmonary vasodilatation, and thereby adjustments of the afterload. The responses found suggest that this may in fact occur and that ANP may play a role in regulating pulmonary blood flow, and thereby the distribution of right ventricular blood flow, in the stressed fetus through its ability to decrease pulmonary vascular resistance.

Acknowledgments. The authors thank Dr. W. F. Ganong for his support and encouragement, Bruce Payne and Carl McWatters for their help with the microsphere data analysis, and Paul Sagan for preparing and editing this manuscript.

\section{REFERENCES}

1. Lang BE, Ruskoaho H, Toth M, Ganten D, Unger T, Dietz R 1987 Mechanisms controlling release of atrial natriuretic peptide. In: Mulrow PJ, Schrier $\mathrm{R}$ (eds) Atrial Hormones and Other Natriuretic Factors. Williams \& Wilkins, Baltimore, MD, pp 19-33
2. Sakamoto M, Nakaok M, Moric N 1986 The lungs as a possible target organ for atrial natriuretic polypeptide secreted from the heart. Biochem Biophys Res Commun 135:515-520

3. Bianchi C, Gutkowska J, Thibault G, Garcia R, Genest J, Cantin M 1985 Radioautographic localization of 125 -I-atrial natriuretic factor (ANF) in rat tissues. Histochemistry 82:441-452

4. Jin H, Yang RH, Thornton RM, Chin YF, Jackson R, Oparil S 1988 Atrial natriuretic peptide lowers pulmonary arterial pressure in hypoxia adapted rats. J Appl Physiol 65:1729-1735

5. Atlas SA, Laragh JH 1987 Physiological actions of atrial natriuretic factor. In: Mulrow PJ, Schrier R (eds) Atrial Hormones and Other Natriuretic Factors. Williams \& Wilkins, Baltimore, MD, pp 53-76

6. Breuhaus BA, Saneii H, Brandt MA, Chimoskey IE 1985 Atriopeptin II lowers cardiac output in conscious sheep. Am J Physiol 249:R776-R780

7. Scheuer DA, Thrasher TN, Quillen Jr FW, Metzler CH, Ramsay DJ 1987 Atrial natriuretic peptide blocks renin response to renal hypotension. Am J Physiol 251:R423-R427

8. Scott JN, Jennes L 1987 Distribution of atrial natriuretic factor in fetal rat atria and ventricles. Cell Tissue Res 248:479-481

9. Sirois P, Gutkowska J 1988 Atrial natriuretic factor immunoreactivity in human fetal lung tissue and perfusates. Hypertension II(suppl I):I-62-I-65

10. Cheung CY, Brace RA 1988 Fetal hypoxia elevates plasma atrial natriuretic factor concentration. Am J Obstet Gynecol 159:1263-1268

11. Ross MG, Ervin MG, Lam RW, Castro L, Leake PD, Fisher DA 1987 Plasma atrial natriuretic peptide response to volume expansion in the ovine fetus. Am J Obstet Gynecol 157:1292-1297

12. Hargrave BY, Iwamoto HS, Rudolph AM 1989 Renal and cardiovascular effects of atrial natriuretic peptide (ANP) in fetal sheep. Pediatr Res 26:1-5

13. Shine P, McDougall JG, Towstoless MK, Wintour EM 1987 Action of atrial natriuretic peptide in the immature ovine kidney. Pediatr Res 22:11-15

14. Iwamoto HS, Rudolph AM, Bristow 1984 Fetal organ metabolism-techniques for catheterization of renal, pulmonary and hepatic veins in fetal sheep. In: Nathanielsz PW (ed) Animal Models in Fetal Medicine. Perinatology Press, Ithaca, NY, pp 1-18

15. Heymann MA, Payne BD, Hoffman JIE, Rudolph AM 1977 Blood flow measurements with radionuclide-labeled particles. Prog Cardiovasc Dis measuremen

16. Ballerman BJ, Brenner BM 1986 Role of atrial peptides in body fluid homeostasis. Circ Res 58:619-630

17. Chou J, Kubota E, Sata $\Upsilon$, Said SI 1986 Comparative relaxant activities of atrial natriuretic peptide (ANPs) and vasoactive intestinal peptide (VIP) on smooth muscle structures in lung. Fed Proc 45:553(abstr)

18. Morice AH, Jansen TL, Brown MJ 1987 The effect of atrial natriuretic factors on in vitro pulmonary artery pressure. Am Rev Respir Dis 135:A300(abstr)

19. Tadepalli AS, Krueger AD 1987 Effect of systemic human atrial natriuretic peptide (ANP) on hypoxic pulmonary vasoconstriction. Fed Proc 46:518(abstr)

20. Turrin M, Gillis CN 1986 Removal of atrial natriuretic peptide by perfused rabbit lungs in situ. Biochem Biophys Res Commun 140:868-873

21. Rudolph AM 1977 Fetal and neonatal pulmonary circulation. Ann Rev Physiol 41:383-395

22. Heymann MA 1984 Control of the pulmonary circulation in the perinata period. J Dev Physiol 6:281-290

23. Thornburg KL, Morton MJ 1983 Filling and arterial pressures as determinants of RV stroke volume in the sheep fetus. Am J Physiol 244:H656-H663 